\title{
Family tree of Catherine Baudoche and Catherine Gronnaix
}

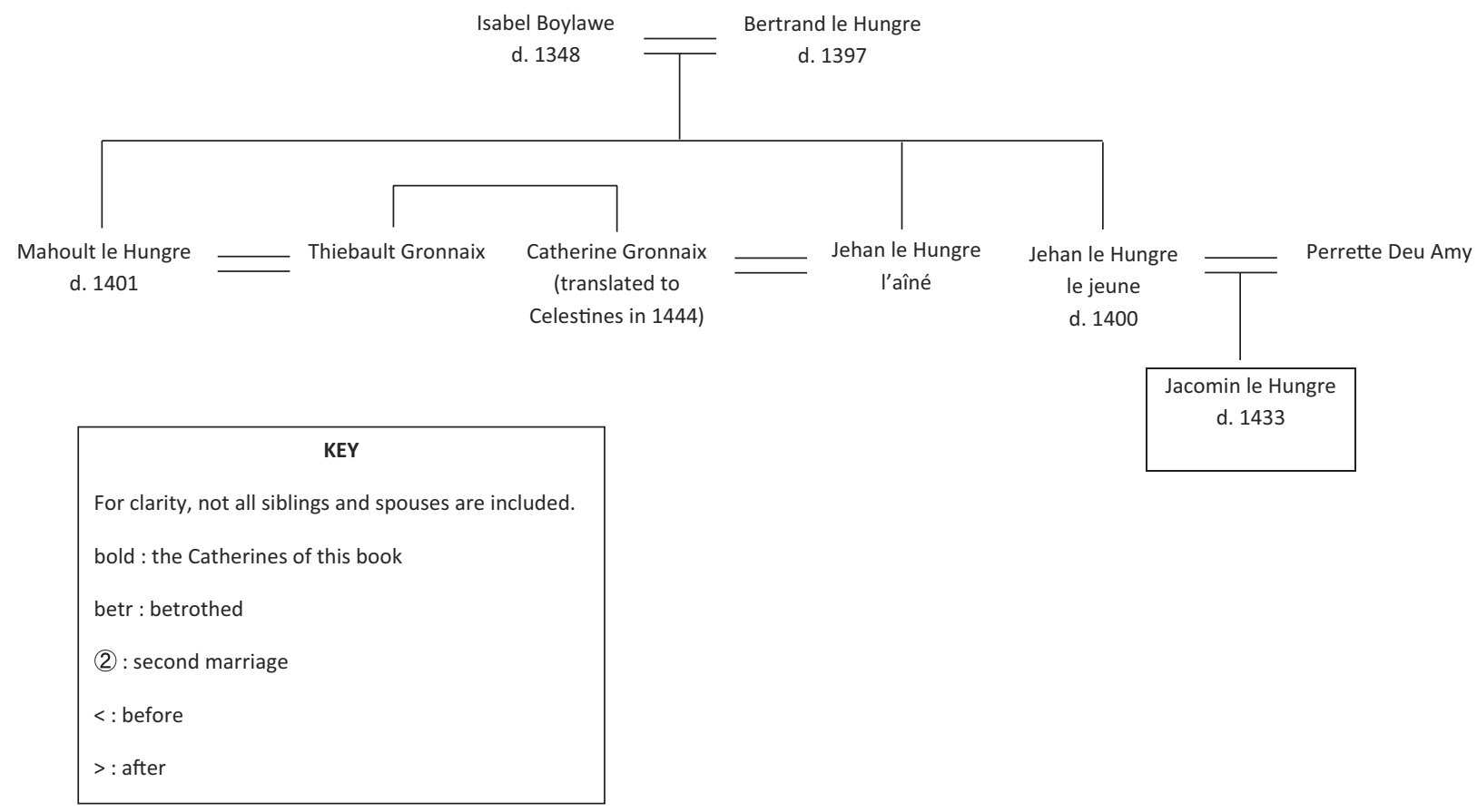




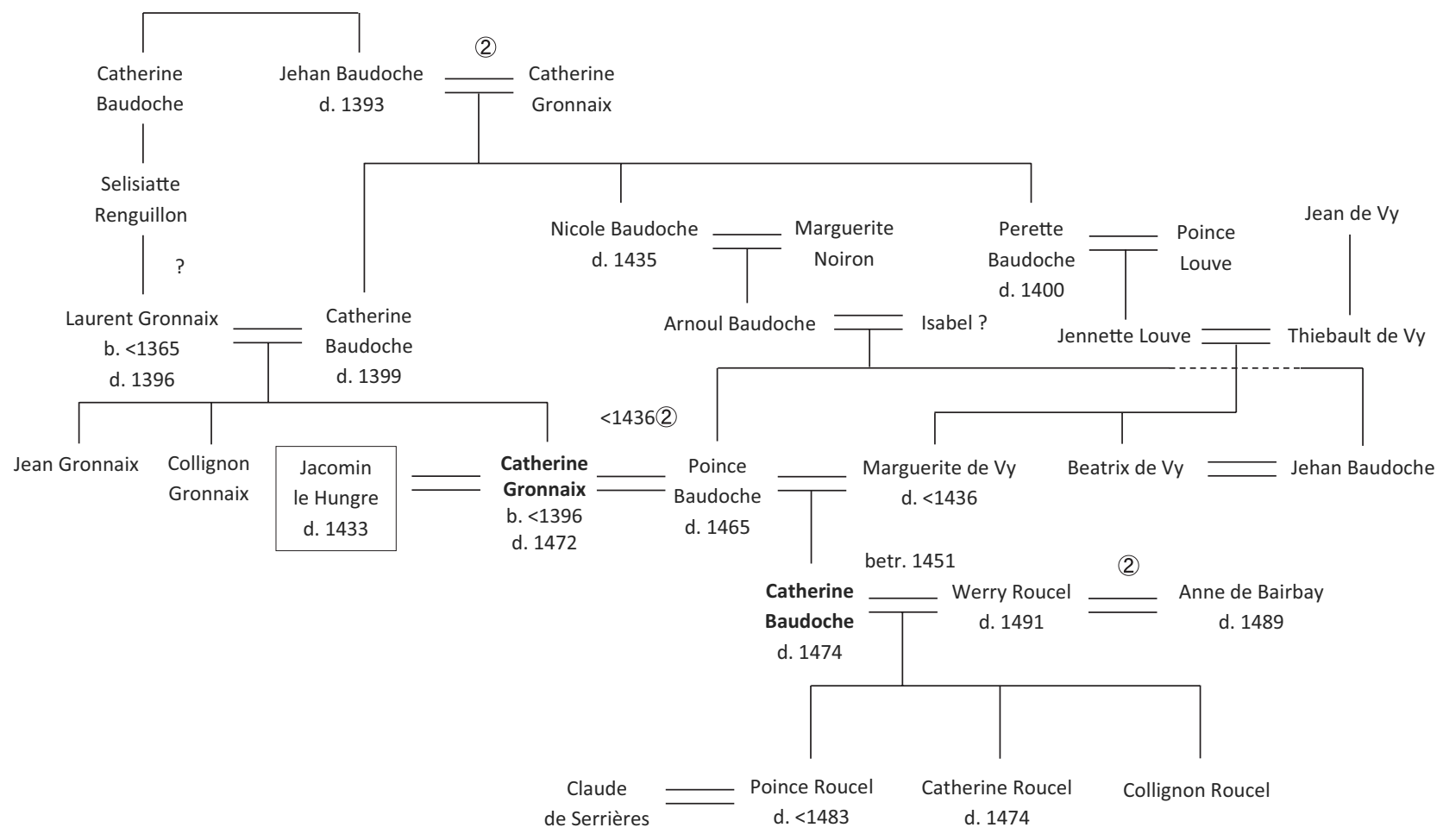


Susannah Crowder - 9781526127242

Downloaded from manchesterhive.com at $04 / 26 / 2023$ 12:38:45PM 